\title{
Kajian Aksiologi Metode STIFIn dalam Pemetaan Mesin Kecerdasan Manusia
}

\author{
Afridha Laily Alindra \\ Mahasiswa Sekolah Pascasarjana Universitas Pendidikan Indonesia \\ E-mail: lailyalindra@gmail.com
}

\begin{abstract}
Abstrak
Metode STIFIn ini merupakan penerapan dari konsep STIFIn yang mengkompilasi dari teori-teori psikologi, neuroscience, dan ilmu sumberdaya manusia. Cara mengetahui mesin kecerdasan ini dengan STIFIn Fingerprint, sebuah tes yang dilakukan dengan cara men-scan kesepuluh ujung jari untuk mendapatkan sidik jari dengan alat fingerprint. Sidik jari yang membawa informasi tentang komposisi susunan syaraf tersebut kemudian dianalisa dan dihubungkan dengan belahan otak tertentu yang dominan berperan sebagai sistem operasi dan sekaligus menjadi mesin kecerdasan seseorang yang diberinama STIFIn yang merupakan singkatan dari sensing (disingkat S), thinking (disingkat T), intuiting (disingkat I), feeling (disingkat F), insting (disingkat In). Dengan menggunakan metode kajian literatur menganalisis bahwa keberadaan mesin kecerdasan dan kepribadian genetik ini mendorong pengembangan potensi kecerdasan manusia yang lebih efektif. Pandangan studi aksiologis metode STIFIn perlu dipelajari secara lebih mendalam, terutama penggunaannya dalam bidang pendidikan.
\end{abstract}

Kata kunci: mesin kecerdasan, kepribadian genetik, aksiologi.

\section{PENDAHULUAN}

Metode STIFIn ini merupakan penerapan dari konsep STIFIn yang mengkompilasi dari teori-teori psikologi, neuroscience, dan ilmu sumberdaya manusia. Prinsip besarnya mengacu kepada konsep kecerdasan tunggal dari Carl Gustaav Jung (Poniman, 2012). Cara mengetahui mesin kecerdasan ini dengan STIFIn Fingerprint, sebuah tes yang dilakukan dengan cara men-scan kesepuluh ujung jari. Sidik jari yang membawa informasi tentang komposisi susunan syaraf tersebut kemudian dianalisa dan dihubungkan dengan belahan otak tertentu yang dominan berperan sebagai sistem operasi dan sekaligus menjadi mesin kecerdasan seseorang. Tes ini juga disebut tes otak karena salah satu komponen terpenting yang dianugerahkan terhadap manusia adalah otak. Ibarat sebuah mesin, otak adalah sebuah mesin yang sangat mengagumkan dan tiada tandingannya (Ramly, 2010). Para ilmuwan menganalisis dan mempelajari otak dengan kemampuan otak mereka. Sehingga muncullah rumusan pembagian otak manusia berdasarkan dominasi kecerdasan. Kecerdasan yang paling dikenal adalah Intelligence Quotient (IQ), yang hampir seratus tahun lalu diperkenalkan oleh William Stern telah menyita perhatian yang tidak kecil (Pasiak, 2008).

Meskipun demikian, kecerdasan dalam STIFIn ini bukanlah mengenai IQ. STIFIn adalah uraian dari sensing (disingkat S), thinking (disingkat T), intuiting (disingkat I), feeling (disingkat F), insting (disingkat In). Menurut konsep STIFIn, bukan belahan otak yang memiliki kapasitas paling besar yang dianggap dominan, melainkan yang kerap digunakan, paling aktif berfungsi, paling otomatis digunakan, dan menjadi bawah sadar manusia (Poniman, 2012).

Dalam pemanfaatannya metode STIFIn saat ini telah banyak digunakan di berbagai bidang guna pemetaan mesin kecerdasan manusia, terutama di bidang pendidikan. Namun demikian penggunaan metode STIFIn dalam berbagai bidang ternyata masih menimbulkan kontroversi. Banyak ahli yang masih mempertanyakan keabsahan metode yang digunakan, dan meminta perbandingan dengan jenis tes kecerdasan lainnya yang telah teruji lebih dahulu, serta berbagai pertanyaan terkait dengan teknis yang masih banyak dilontarkan.

Berkaitan dengan isu yang disampaikan pada paragraf sebelumnya, maka penulis akan 
mengkaji perihal aksiologi metode STIFIn dalam pemetaan mesin kecerdasan manusia yang sebenarnya memiliki banyak manfaat untuk berbagai tujuan. Kajian ini diharapkan memberikan pandangan tentang kepantasan pemanfaatan metode STIFIn dalam pemetaan mesin kecerdasan dan seberapa besar potensi atau manfaat yang diperoleh dari metode STIFIn tersebut.

\section{METODE}

Metode yang digunakan adalah metode studi kepustakaan. Penelaahan terhadap buku-buku, literatur-literatur, dan artikel ilmiah dilakukan untuk memperkaya kajian tentang metode STIFIn. Data sekunder dari berbagai hasil penelitian atau percobaan merupakan jenis data yang kemudian disintesis hingga menjadi kesatuan dalam memberikan informasi.

\section{HASIL DAN PEMBAHASAN}

\section{Sejarah Penemuan Metode STIFIn}

Sejarah perjalanan metode STIFIn dimulai tahun 1999 ketika Farid Poniman bersama rekanrekannya mendirikan lembaga training Kubik Leadership. Lembaga training tersebut setiap memulai program trainingnya terlebih dahulu memetakan peserta training sesuai dengan jenis kecerdasannya. Sebagai konsep, STIFIn kala itu bisa dibilang masih embrio. Perbaikan konsep dilakukan di sana-sini seiring dengan berkembangnya penyelenggaraan training Kubik Leadership. Namun, kala itu, tesis atau hipotesisnya sudah matang dan kukuh bahwa manusia memiliki kecerdasan genetik (Poniman, 2012).

\section{Teori yang Mendasari Metode STIFIn}

Konsep STIFIn ini dibangun berdasarkaan teori-teori yang dielaborasi dari para ahli di masingmasing bidang. Menurut Poniman (2012) terdapat empat teori yang menjadi dasar pijakan konsep STIFIn, yaitu:

1) Teori Fungsi Dasar dari perintis psikologi analitik berkebangsaan Swiss bernama Carl Gustav Jung yang mengatakan bahwa terdapat empat fungsi dasar manusia yakni fungsi penginderaan (Sensing), fungsi berpikir (Thinking), fungsi merasa (Feeling), dan fungsi intuisi (Intuition). Dari empat fungsi dasar itu, hanya salah satu diantaranya ada yang dominan.

2) Teori Belahan Otak dari seorang neurosaintis Ned Hermann yang membagi otak menjadi empat kuadran yakni limbik kiri dan kanan, serta cerebral kiri dan kanan.

3) Teori Strata Otak Triune (tiga kepala menyatu) dari neurosaintis lain yang

4) berkebangsaan Amerika, Paul MacLean yang membagi otak manusia berdasarkan hasil evolusinya: otak insani, mamalia, dan reptilia.

\section{Hasil Sintesa dari Konsep STIFIn}

Konsep STIFIn bukan sekedar mengubah dari 3 kotak (MacLean) menjadi 4 kotak (Jung dan Hermann) kemudian menambahkan kotak ke -lima menjadi STIFIn. Fakta bahwa STIFIn bisa menjelaskan banyak hal, membuktikan bahwa konsep ini memiliki hal-hal baru hasil sintesa. STIFIn memiliki hal-hal berikut ini:

1. Teori menyilang sebagai superior dan inferior dalam satu paket. Teori ini menjelaskan tentang adanya hubungan silang antarmesin kecerdasan $S-I$ dan $T$ - F yang mana masing-masing memiliki sifat superior dan inferior.

2. Teori irisan persamaan (di antara kutub perbedaan pada kuadran dan diagonal). Meski ada perbedaan pada masing-masing mesin kecerdasan, STIFIn menegaskan bahwa ada kesamaan sifat yang saling beririsan satu sama lain, seperti:

a. MK Thinking - Intuiting memiliki kesamaan irisan dalam pekerjaan investigasi (penelitian dan penyelidikan terhadap sesuatu) dan analisa. Selain itu, kedua MK ini begitu menonjol 
sebagai konseptor dan pelaksana konsep yang disusunnya.

b. MK Sensing - Feeling beririsan sama dalam hal berhubungan dengan orang lain (social relationship). Sensing sangat kuat dalam berhubungan dan berinteraksi dengan orang lain, sedangkan Feeling juga sangat menonjol dalam pertemanan, persahabatan dengan orang lain.

c. MK Thinking - Sensing sama-sama menyukai keteraturan, prosedural dan memiliki daya tahan secara fisik dibandingkan MK yang lain (Intuiting, Feeling dan Instinct).

d. MK Intuiting - Feeling, keduanya menonjol dalam hal ide-ide artistik, dan berpikir dari global ke detil.

e. MK Sensing - Intuiting, memiliki kesesuaian dalam hal menghasilkan suatu produk. Kduanya juga sangat cocok sebagai unsur top management, ataupun sebagai komisaris perusahaan. Jika keduanya berada pada satu perusahaan akan saling menguatkan sebagai salah satu unsur di atas.

f. MK Feeling - Thinking, berkesesuaian dalam bidang pengelolaan organisasi. Apabila keduanya berada dalam satu organisasi dimana keduanya sama-sama mengelola maka akan sangat baik dan berjalan secara efektif sebagai tim.

3. Teori hubungan sosial segi lima yang unik dan logis (Teori Sirkulasi STIFIn). STIFIn juga menguraikan adanya hubungan antarMK sebagai bentuk interaksi sosial, dalam dua kondisi, yaitu (a) hubungan saling mendukung, dan (b) hubungan saling menaklukkan.

4. Teori keselarasan metabolisme tubuh berdasarkan mesin kecerdasannya. Konsep STIFIn yang berkaitan dengan kondisi biologis seseorang dijelaskan dalam keselarasan antara kecerdasan dengan unsur metabolisme masing-masing MK, yaitu:
a. Sensing - organ sistem pencernaan (lambung)
b. Thinking - organ sistem eksresi (ginjal)
c. Intuiting - organ sistem sintesa (hati/liver) dan sistem saraf
d. Feeling - organis sistem respirasi/pernapasan
e. Instinct - organ sitem peredaran darah dan pusat keseimbangan

5. Teori kalibrasi berdasarkan mesin kecerdasannya. STIFIn mengungkap terhadap bagaimana setiap mesin kecerdasan melepaskan dari tekanan dan mendapatkan kembali kondisi terbaiknya. Berikut ini adalah masing-masing kalibrasi pada setiap mesin kecerdasan.

6. Teori genetika sesuai mesin kecerdasannya. Berdasarkan mesin kecerdasan dan drive kecerdasan tadi, maka STIFIn mengelompokkan genetik kepribadian atau kecerdasan menjadi sembilan kelompok, yaitu: $\mathrm{Si}$ - Sensing introvert; $\mathrm{Se}$ - Sensing extrovert; $\mathrm{Ti}$-Thinking introvert; $\mathrm{Te}$ - Thinking extrovert; li - Intuiting introvert; le - Intuiting extrovert; Fi - Feeling introvert; Fe - Feeling extrovert; In - Instinct.

7. Teori strata genetik. Konsep STIFIn membagi membuat peringkat urutan terhadap genetik manusia. Berikut ini urutan stratea genetikan dari yang tertinggi ke rendah, yaitu:
a. Jenis kelamin;
b. Mesin kecerdasan;
c. Drive kecerdasan;
d. Kapasitas hardware; dan
e. Golongan darah.

\section{Perbandingan konsep STIFIn dengan konsep Multiple Intelligence Howard Gardner dan MBTI}

Menurut Gardner (2003) kecerdasan seseorang mempunyai sembilan aspek yang disebut dengan istilah Multiple Intelligence atau kecerdasan majemuk. Kesembilan aspek itu adalah kecerdasan verbal-linguistik, kecerdasan logika-matematika, kecerdasan kinestetik-badani, kecerdasan spasial (ruang-tempat), kecerdasan bermusik, kecerdasan interpersonal, kecerdasan intrapersonal, kecerdasan naturalis, dan kecerdasan eksistensial. Setiap peserta didik memiliki kecerdasan majemuk, tetapi pada masing-masing mereka ada aspek-aspek yang paling menonjol. 
Menurut Gardner peserta didik ternyata lebih mudah belajar atau menangkap bahan yang diajarkan pendidik bila bahan itu disajikan sesuai dengan kecerdasan peserta didik yang menonjol. Kecerdasan matematis-logis lebih berkaitan dengan penggunaan bilangan dan logika secara efektif, kepekaan pada pola logika, abstraksi, kategorisasi dan perhitungan.Kecerdasan verbal-linguistik adalah kemampuan untuk menggunakan kata-kata secara efektif baik secara oral maupun tertulis. Kemampuan ini berkaitan dengan penggunaan dan pengembangan bahasa secara umum. Kecerdasan kinestetikbadani adalah kemampuan yang berkaitan dengan kegiatan fisik atau ragawi, kemampuan memainkan peran, dan membentuk bangunan model serta keterlibatan dalam permainan olahraga. Karya Howard Gardner ini memiliki dampak besar pada pemikiran dan praktik dalam pendidikan terutama di Amerika Serikat. Teori kecerdasan majemuk Howard Gardner belum diterima sepenuhnya dalam psikologi akademik. Namun, ia telah mendapatkan respon positif dari banyak pendidik. Teori ini telah dianut oleh berbagai teori pendidikan dan secara signifikan, diterapkan oleh guru dan pembuat kebijakan sekolah. Sejumlah sekolah di Amerika Utara memiliki struktur kurikulum menurut kecerdasan, dan merancang ruang kelas dan bahkan seluruh sekolah untuk mencerminkan pemahaman tentang teori ini (Smith, 2002).

Beberapa perbandingan antara konsep STIFIn dengan konsep Multiple Intelligence (MI) Howard Gardner menurut Poniman \& Rahman (2013) sebagai berikut:

1. STIFIn mengacu kepada kecerdasan tunggal ala Jung, yang berarti meskipun kesemua belahan otak berfungsi tetapi secara mutlak dikendalikan oleh satu belahan otak yang aktif berperan sebagai pemimpin bagi keseluruhan otak. Sedangkan pada MI setiap belahan otak dapat berfungsi secara bersamaan secara proporsional.

2. MI membagi kecerdasan menjadi 9 , sedangkan pada STIFIn hanya 5 . Pada STIFIn yang 9 itu adalah personaliti genetik (selanjutnya disebut $P G$ ).

3. Perbandingan antara 9 PG STIFIn dengan 9 kecerdasan MI:

a. Kecerdasan Interpersonal setara dengan PG tipe Fe (Soc-Q)

b. Kecerdasan Intrapersonal setara dengan PG tipe Fi (EQ)

c. Kecerdasan Logika Matematika setara dengan PG tipe Te (LQ)

d. Kecerdasan Visual Spasial setara dengan PG tipe le (Spa-Q)

e. Kecerdasan Body Kinestetik setara dengan PG tipe Se (PQ)

f. Kecerdasan Verbal Linguistik setara dengan PG tipe Si (MQ)

g. Kecerdasan Musikal, Kecerdasan Naturalis, dan Kecerdasan Spiritual setara dengan PG tipe $\ln (A Q)$

Selanjutnya, menurut Tyagi (2008) hari ini, di seluruh dunia, instrumen psikologis yang berbeda digunakan menentukan berbagai atribut kepribadian manusia. Salah satu tes untuk memahami kedalaman kepribadian adalah tes psikometri, yaitu MBTI (Myers Briggs Type Indicator). MBTI, dikembangkan pada awal 1950-an oleh Katherine Cook Briggs dan Isabel Briggs Myers, dirancang untuk membuat teori Jung lebih eksplisit dan praktis dalam penerapannya kehidupan sehari-hari. Sejak publikasi pada tahun 1955, MBTI semakin banyak digunakan dalam pendidikan, konseling, bisnis, pemerintah dan komunitas agama (McCaulley, 1987 dalam Tyagi, 2008). Campbell dan Davis (1988 dalam Tyagi, 2008) melaporkan bahwa lebih dari 1.100 disertasi, tesis, buku, dan artikel jurnal telah dipublikasikan di MBTI. MBTI saat ini inventaris yang paling banyak digunakan jenis psikologis di dunia (Hirsh \& Kummerow, 1989 dalam Tyagi, 2008).

MBTI mengukur preferensi pada empat dimensi, yang telah dijelaskan oleh Hirsh dan Kummerow (1989 dalam Tyagi, 2008). Mereka, mengklasifikasikan empat dimensi sebagai berikut:

1. Energizing: Bagaimana dan di mana anda dapatkan energi

2. Attending : Apa yang anda perhatikan ketika mengumpulkan informasi

3. Deciding: Sistem apa yang anda gunakan saat anda membuat keputusan.

4. Living: Apa jenis kehidupan yang akan anda adopsi.

Dimensi kedua dan ketiga mengacu pada kekuatan mental atau dimensi kognitif dan sering dianggap dimensi yang paling penting. Dimensi yang pertama dan keempat kategori mengacu pada 
sikap. Mereka menggambarkan di mana kita mendapatkan energi dan bagaimana kita berurusan dengan dunia luar. Setiap dimensi memiliki dua kutub. Dimensi yang pertama, Energizing mengacu pada orientasi seseorang terhadap dunia. Kedua kutub dimensi ini adalah introversi dan ekstroversi. Dimensi kedua, Attending, merujuk bagaimana seseorang mempersepsikan informasi. Dua kutub dari kategori ini sensing dan intuitiv. Dimensi ketiga, Deciding, mengacu pada bagaimana seseorang membuat keputusan. Kedua kutub dimensi ini adalah feeling dan thinking. Feeling cenderung sangat selaras dengan perasaan mereka sendiri dan perasaan orang lain. Mereka mendasarkan keputusan mereka tentang apa yang penting untuk diri mereka sendiri dan orang lain. Thinking, di sisi lain, mendasarkan keputusan mereka pada suatu tujuan, impersonal, dan analisis logis dari suatu situasi. Mereka sering fokus pada sebab-akibat hubungan dan mencari standar obyektif kebenaran.

Adapun perbandingan STIFIn dengan MBTI menurut Poniman \& Rahman (2013) dapat dijelaskan sebagai berikut: MBTI terbagi dalam 16 jenis personaliti sedangkan STIFIn 9 personaliti. Pertama, ke 16 personaliti MBTI itu diukur berdasar perilaku, sedangkan STIFIn memetakan secara genetik dengan mengetahui dominasi belahan otak dan lapisan otak. Perbedaan kedua, unsur Judging dan Perceiving pada MBTI berdiri sendiri sedangkan menurut STIFIn mereka melekat pada diagonal produksi dan organisasi sehingga tidak perlu eksis sendiri. Perbedaan ketiga, pada STIFIn fungsi introvert dan extrovert hanya sekedar drive (pengemudi) kepada fungsi dasar sedangkan pada MBTI mereka berdiri setara dengan fungsi dasar yang lain. Perbedaan keempat, pada MBTI tidak menyebutkan adanya fungsi dasar Insting (In).

\section{Tingkat Akurasi Tes STIFIn}

Berdasarkan hasil riset yang dilakukan oleh lembaga independen, dari 352 orang yang melakukan tes ulang, satu bulan setelah tes sebelumnya, hanya 3 orang yang hasilnya berubah. Dengan demikian akurasinya di atas $95 \%$. Sedangkan berdasarkan data dari STIFIn sendiri, sebagian besar dari 60 ribu orang lebih yang sudah melakukan tes STIFIn mengaku bahwa apa yang ditampilkan dari hasil tes itu menjelaskan secara baik apa yang mereka rasakan selama ini. Tidak kurang $95 \%$ dari mereka yang sudah menggunakan alat test STIFIn itu menyatakan ekspresi mereka setelah tes sebagai, "gua banget" atau "kok bisa pas sih" atau "jadi malu aku seperti ditelanjangi" atau "kok bisa ya?" dan berbagai komentar senada lainnya. Maka, meski alat tes ini memiliki ruang untuk diperbaiki, namun akurasinya saat ini sudah mapan di atas 95\% (Poniman, 2012).

Tes STIFIn ini mengukur unsur genetik seseorang, sesuatu yang dibawa lahir dan tidak berubah sepanjang hayat. Sedangkan alat seperti pencil and paper test seringkali hanya bisa mengukur fenotip seseorang, sesuatu yang tampak secara lahiriah ketika tes sedang dilaksanakan. Itu sama artinya dengan tampilan yang berubah sesuai dengan kondisi lingkungan. Ahli kedokteran olahraga dari University of London, Nicola Maffulli, mengatakan faktor gen menemukan 30-60 persen keberhasilan latihan fisik orang biasa. Pada atlet, gen menentukan keberhasilan hingga 83 persen. Sedang menurut Stephen Roth ahli genetika dari University of Maryland di Baltimore, 80 persen kemampuan fisik ditentukan oleh gen bukan oleh latihan (Koran Tempo 2 Agustus 2012 halaman A12).

Rumus Fenotip 100\% = Genetik 20\% + Lingkungan $80 \%$ ini membuat tak sedikit manusia galau dan tak kurang pula banyaknya yang lebay. Lingkunganlah yang menempati porsi terbesar dalam pengembangan diri. Tapi, genetik yang meski porsinya hanya sekitar 20 persen tapi sangat menentukan. Ini mirip seperti; Hukum Dari Yang Sedikit (law of the vital few) dimana yang sedikitlah yang dominan atau penentu.

\section{Perkembangan Penemuan dan Keunggulan Metode STIFIn}

Setelah dilakukan riset untuk sekian lama, menurut Poniman (2012) kini konsep STIFIn sudah cukup kokoh. Kekuatan utamanya terletak pada konsep yang simpel, akurat, dan aplikatif.

\section{Simpel}

Dikatakan simpel karena penjelasannya sederhana dan dari miliaran manusia, oleh STIFIn dikelompokkan hanya dalam 5 mesin kecerdasan dan 9 personality genetic. Sehingga tidak dipusingkan lagi dengan pengelompokan manusia dalam banyak kotak, seperti MBTI dan Socionics 
yang mengelompokkan dalam 16 kotak. Lima mesin kecerdasan itu mencakup seluruh jenis kecerdasan yang ada yang dimiliki manusia di muka bumi ini.

Konsep STIFIn disebut simpel karena bersifat multy-angle theory. Artinya, STIFIn dapat dipakai untuk menjelaskan teori kecerdasan dan personaliti dari disiplin ilmu yang lain. Seperti konsep otak kiri dan otak kanan (Roger W. Sperry) atau pembagian neokortek sebagai otak atas dan limbik sebagai otak bawah (Paul Broca) atau pembagian 6 Hexagonal Holland (John Holland) juga konsep DISC (John Geier dan Thomas International) atau bahkan teori lama Hippocrates dan Galenus dapat dengan mudah dibedah menggunakan STIFIn. Uraian persamaannya sebagai berikut:

a. Otak kiri dan otak kanan sama dengan $S+T$ dan I + F pada STIFIn.

b. Neokortek dan limbik sama dengan $\mathrm{T}+\mathrm{I}$ dan $\mathrm{S}+\mathrm{F}$ pada STIFIn

c. 6 Hexagonal Holland: Artistic-Realistic (identik dengan Kanan-Kiri STIFIn), InvestigativeSocial (identik dengan Atas Bawah STIFIn), Conventional Enterprising (identik dengan diagonal Organisasi- Produksi STIFIn).

d. D-I-S-C pada John Geier dan Thomas International identik dengan S-F-I-T pada STIFIn.

e. Kholeris, Flegmatis, Melancolis, dan Sanguinis sama dengan S, T, I, dan F pada STIFIn.

Penemuan sebuah teori kepribadian baru tidak terlepas dari teori-teori sebelumnya yang menjadi pijakan dan landasan bagi pengembangan teori-teori tersebut. Penemu STIFIn meyakini bahwa segala hal yang melekat pada diri individu terdapat belahan otak yang bekerja paling dominan. Belahan otak tersebut yang memberikan kontribusi kepada diri individu seutuhnya. Sifat-sifat dari belahan otak tersebut kemudian membuat konstitusi tubuh menjadi selaras dengan berbagai fungsi tubuh yang melekat secara genetik pada jenis individu tertentu.

Aplikasi lain yang menarik adalah ketika konsep STIFIn digunakan untuk praktik penggemblengan diri dengan prinsip fokus-satu-hebat. Konsep kecerdasan tunggal yang dianut STIFIn lebih mampu menjelaskan realitas otak dalam keseharian. Itulah penjelasan kenapa konsep STIFIn yang menganut kecerdasan tunggal lebih aplikatif dibandingkan konsep kecerdasan majemuk atau Multiple Intelligence (MI) yang bisa digambarkan dengan menggunakan metafora sederhana: kepemimpinan ayah dalam keluarga. Menurut konsep STIFIn setiap orang memiliki seluruh otak, namun hanya ada satu yang memimpin (sebaliknya menurut $\mathrm{Ml}$ ada dua, tiga, atau empat yang dominan). "A specialist in the construction of the whole" kata Daoed Joesoef.

\section{Akurat}

Metoda STIFIn menguraikan cara kerja otak berdasarkan sistem operasinya, bukan kapasitas hardware-nya. Yang dimaksud hardware adalah perangkat keras, sedangkan sistem operasi adalah yang berfungsi menghubungkan antara perangkat keras dengan aplikasi, seperti Microsoft Windows, Linux, Android, dan Macintosh. IQ (intelligence quotient) itu adalah perangkat keras. Dengan demikian, mengukur IQ sama dengan mengukur kapasitas hardware, dan bukan untuk mengetahui jumlah sambungan denrit antarsel otak yang sesungguhnya menentukan IQ seseorang.

Berbeda dengan konsep yang lain, STIFIn menggunakan sistem operasi yang berbicara tentang jenis watak kecerdasan. Tiap jenis kecerdasan punya wataknya sendiri-sendiri. Jenis watak kecerdasan itulah yang kemudian disebut sebagai mesin kecerdasan. Jadi, STIFIn memetakan otak bukan berdasarkan belahan otak yang paling besar volumenya, melainkan berdasarkan belahan otak yang paling kerap digunakan. Itulah yang disebut sebagai sistem operasi. Membagi otak berdasarkan belahan otak yang berperan sebagai sistem operasi inilah yang membuat STIFIn akurat.

\section{Aplikatif}

Disebut aplikatif karena konsep STIFIn bercirikan multiangle field yang kurang lebih artinya, STIFIn dapat dipakai untuk menjelaskan bidang apa saja. STIFIn dapat diaplikasikan pada bidang learning, profession, parenting, couple, politic, human resources, dan bidang-bidang lainnya. 


\section{Mekanisme Metoda STIFIn}

Langkah awal adalah mengikuti tes STIFIn melalui sidik jari. Dari hasil ini setelah dianalisa menggunakan alat scan akan didapatkan informasi tentang:

\section{Belahan Otak Dominan}

Dengan di tes STIFIn Anda akan mengetahui secara cepat, tepat, dan akurat (dalam waktu 10 menit setelah di tes) dimanakah belahan otak Anda yang paling dominan. Bisa dibelahan kiri, kanan, ataupun tengah. Dari diketahuinya belahan otak mana yang dominan pada diri Anda, maka akan diketahui apakah jenis kecerdasan Anda (Sensing, Thinking, Intuiting, Feeling, atau Insting).

2. Lapisan Otak Dominan

Kemudian setelah diketahui dimanakah dominan belahan otak Anda, maka berikutnya kita bisa mengetahui dimanakah lapisan otak dominan Anda, apakah itu lapisan otak dalam (putih) ataupun lapisan otak luar (abu-abu). Dari lapisan otak tersebut akan menentukan Personaliti Genetik Anda apakah introvert ataukah extrovert. Skema mesin kecerdasan STIFIn dapat dilihat pada gambar 1 berikut:

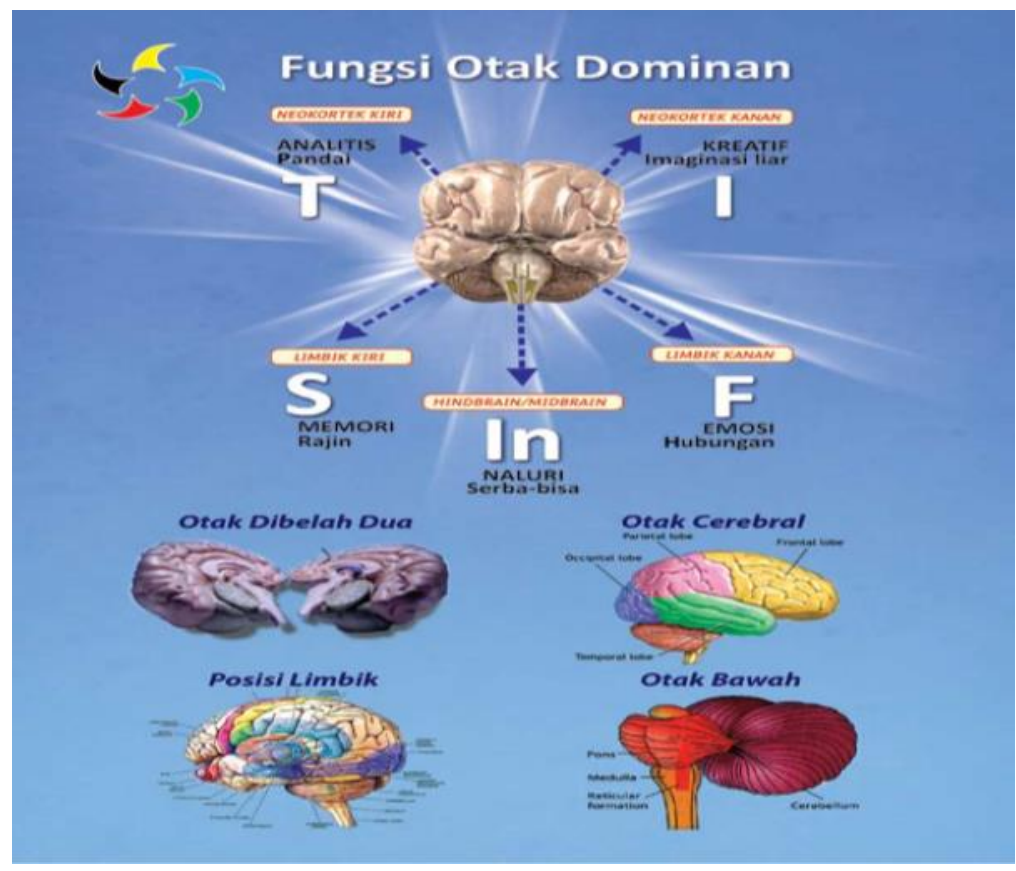

Gambar 1. Skema Mesin Kecerdasan STIFIn (Poniman, 2012)

\section{Tinjauan Aksiologis Metode STIFIn}

Suriasumantri (2010) menyatakan bahwa filsafat ilmu merupakan telaahan secara filsafat yang hendak menjawab pertanyaan mengenai hakikat ilmu, baik ditinjau dari sudut ontologi, epistemologi dan aksiologi. Aksiologi sebagai bagian dari cabang filsafat ilmu yang membahas teori penggunaan ilmu pengetahuan. Aksiologi mencakup nilai dan penilaian dari suatu objek yang berhubungan dengan etika dan estetika. Etika membicarakan perilaku manusia, sedangkan estetika memandang karya manusia dari sudut yang baik dan buruk (Wiramihardja, 2009). Etika sangat terkait dengan filsafat moral dengan mengkaji prinsip-prinsipnya pada prilaku seseorang (Firman, 2018). Dalam kaitannya dengan sains, etika sains berarti membahas prilaku moral yang terkait dengan hakikat sains sebagai ilmu pengetahuan.

Pengetahuan semakin berkembang dengan hadirnya teknologi sebagai suplemennya. Metode STIFIn mengakomodir teknologi dalam pengaplikasian konsep pengetahuan tentang mesin kecerdasan melalui pola sidik jari. Keberadaan mesin kecerdasan dan personality genetic seseorang akan menentukan pola perilaku, kepribadian dan kecerdasannya. Keberadaan mesin kecerdasan dan 
personality genetic inilah yang mendorong terwujudnya pengembangan atas seluruh aspek potensi kecerdasan manusia yang lebih efektif dan adekuat terhadap semua bidang.

Dalam praktek di dunia pendidikan, menurut Nistiningtyas (2013) terdapat beberapa alasan mengapa memilih metode STIFIn yaitu:

1. Guru bisa dengan mudah mengenali cara belajar masing- masing peserta didik yang berbedabeda. Mesin kecerdasan Sensing (S) bagus dalam menghafal, Thingking $(T)$ hebat dalam menghitung, Intuiting (I) jago dalam kreatifitas, Feeling (F) senang jika berdiskusi, dan Insting (In) pembelajar serba-bisa namun memerlukan ketenangan untuk mengoptimalkan fungsi otak tengahnya (naluri).

2. Memilih profesi secara jitu dengan mudah. Jika pilihan profesi sudah menyatu atau sesuai dengan keinginan. Maka proses pengglembengan profesi menjadi mudah dan menyenangkan meskipun digembleng dengan cara yang sangat berat (massif).

3. Memilih Tes STIFIn sama dengan menghindari spekulasi. Bukan pelabelan atau peramalan. Pada setiap mesin kecerdasan dan personality terdapat kelebihan dan kelemahan dalam satu paket. Tes STIFIn bukan melabelkan seseorang, karena paket kelebihan dan kelemahan seseorang itu ditemukan kesejatiannya secara meyakinkan, tidak semu dan tidak nujum, atau tilikan. Kesuksesan yang diraih dengan berusaha di jalan yang tepat menggunakan jalur mesin kecerdasan, bukanlah ramalan sukses yang datang dari garis tangan (seperti pada palmistry).

Dengan demikian, peserta didik lebih merasa nyaman dan enjoy dalam proses pembelajaran. Mereka bisa menyesuaikan gaya belajar yang sudah mereka ketahui melalui hasil test tersebut. Yang terjadi selanjutnya adalah peserta didik lebih terkonsentrasi dan menekuni mesin kecerdasan yang telah teridentifikasi pada dirinya. Sehingga guru pun akan lebih memaklumi dan lebih menaruh perhatian yang maximal terhadap kemajemukan mesin kecerdasan tiap- tiap peserta didik. Hal ini akan berdampak pada peningkatan prestasi belajar peserta didik. Rafianti \& Pujiastuti (2017) juga menyatakan dalam hasil penelitiannya dalam dunia pendidikan saat ini sudah dikenal berbagai metode untuk memenuhi tuntutan perbedaan individu, salah satunya adalah STIFIn yaitu metode untuk menentukan dominasi kecerdasan mesin untuk membuat siswa lebih nyaman dalam proses pembelajaran sehingga diharapkan dapat meningkatkan daya matematis siswa. Seiring dengan itu, Gunadi (n.d) dalam kajian tentang pengembangan model kepemimpinan sekolah dengan pendekatan metode STIFIn dinyatakan bahwa:

1. Mesin kecerdasan yang dimiliki oleh pemimpin/kepala sekolah dan guru/tenaga kependidikan akan menentukan gaya dalam memimpin (bentuk interaksi komunikasi) yang dilakukan.

2. Dengan mesin kecerdasan dan personality genetic yang dimiliki kepala sekolah akan dengan mudah mengendalikan bawahannya sesuai dengan mesin kecerdasan dan personalitiy genetic.

3. Proses interaksi - komunikasi efektif dilakukan dengan saling memahami masing-masing PG. Kepala sekolah akan melakukan proses interaksi - komunikasi kepada bawahan (guru dan tenaga kependidikan) sesuai dengan PG-nya. Demikian, pula sebaliknya, bawahan dapat memperlakukan kepala sekolah dengan baik.

Seiring dengan itu, Mundiri \& Irma (2017) berpendapat yang menjadi suatu permasalahan dalam materi hapalan adalah ketika seseorang menghafal menggunakan cara yang tidak sesuai dengan sistem kinerja otak, pada akhirnya akan menyebabkan hafalan mudah lupa bahkan orang tersebut merasa tertekan selama proses menghafal. Ini dapat disebabkan karena setiap manusia memiliki sistem kinerja otak dan kepribadian yang berbeda-beda, maka memerlukan penanganan yang berbeda-beda pula sesuai dengan kinerja otak masing-masing dalam proses menghafal. Karenanya metode STIFIn dapat membantu mengatasi permasalahan ini.

Selanjutnya menurut Ratna \& Ridwan (2017) dalam hasil penelitian mereka tentang aplikasi pengembangan karakter siswa, dilakukan oleh guru dengan terlebih dahulu memahami karakter pada setiap peserta didik kemudian mengenali bakatnya dan selanjutnya menyalurkan bakatnya ke dalam kegiatan pengembangan diri. Hal ini dilakukan dengan menggunakan tes STIFIn, untuk mengenali minat, bakat, berpikir kreatif, logis, kerja otak kiri dan otak kanan seseorang, keseluruhannya ditinjau 
dari psikometri seseorang yang prinsipnya diketahui dengan membaca sepuluh jari seseorang.

Adapun pemanfaatan metoda STIFIn di bidang yang lain seperti pada bidang managerial berbagai instansi dan lembaga. Pola kepemimpinan dengan menggunakan metoda STIFIn dipercaya dapat membangun pola hubungan antara pimpinan dengan bawahan yang lebih efektif dan kondusif karena masing-masing pihak telah memahami karakter berdasarkan mesin kecerdasan dan personality genetic masing-masing. Sehingga iklim yang terbangun semakin kondusif untuk mencapai tujuan organisasi.

Sejauh ini memang masih banyak eksplanasi ilmiah yang masih diperlukan dari metoda STIFIn. Peluang penelitian lebih lanjut amat terbuka untuk hal ini. Kajian ilmiah tentang kaitan pola genetika dengan kecenderungan mesin kecerdasan masih sangat perlu dikembangkan. Keterlibatan neurosains yang lebih mendalam tentu akan lebih diperlukan, sehingga kajian tentang metode STIFIn yang sedang digunakan secara massif ini dapat lebih diterima secara ilmiah.

\section{PENUTUP}

Metode STIFIn ini merupakan penerapan dari konsep STIFIn yang mengkompilasi dari teori-teori psikologi, neuroscience, dan ilmu sumberdaya manusia. Cara mengetahui mesin kecerdasan ini dengan sebuah tes yang dilakukan dengan cara men-scan kesepuluh ujung jari untuk mendapatkan sidik jari dengan alat fingerprint. Sidik jari yang membawa informasi tentang komposisi susunan syaraf tersebut kemudian dianalisa dan dihubungkan dengan belahan otak tertentu yang dominan berperan sebagai sistem operasi dan sekaligus menjadi mesin kecerdasan seseorang yang dikelompokkan dalam lima yaitu sensing (disingkat S), thinking (disingkat T), intuiting (disingkat I), feeling (disingkat F), insting (disingkat In).

Dalam perspektif kajian filsafat ilmu, aksiologi metoda STIFIn ini dibahas dari teori penggunaan ilmu pengetahuan. Metoda yang telah melalui kajian cukup panjang dan mendasari pada teori-teori dari ahli yang terlebih dahulu membuat metoda ini menjadi hal yang layak untuk dikaji aspek pemanfaatan nya yang secara luas telah digunakan ditengah masyarakat.

\section{REFERENSI}

Firman, H. (2018). Filsafat Sains. Program studi Pendidikan IImu Pengetahuan Alam, Sekolah Pascasarjana, Universitas Pendidikan Indonesia. Tidak diterbitkan.

Gardner, H. (2003). Multiple Intelligences: The Theory in Practice. New York : John Wiley.

Gunadi, I. n.d. Pengembangan Model Kepemimpinan Sekolah dengan Pendekatan Konsep STIFIn. Di akses di: https://www.academia.edu/34614271/Pengembangan_Model_Kepemimpinan_Sekolah_dengan_Pende katan_Konsep_STIFIn. Tanggal akses: 4 April 2018.

Mundiri, A., \& Zahra, I. (2017). Implementasi Metode STIFIn Dalam Meningkatkan Kemampuan Menghafal AlQur'an Di Rumah Qur'an STIFIn Paiton Probolinggo. Jurnal Pendidikan Agama Islam (Journal of Islamic Education Studies), 5(2), 201-223. http://dx.doi.org/10.15642/jpai.2017.5.2.201-223

Nistiningtyas. (2013) Tes STIFIn dalam Mencapai Prestasi Belajar Siswa pada Mata Pelajaran Tarikh di Kelas Viil di SMP IT Al- Amri Probolinggo. Undergraduate thesis, UIN Sunan Ampel Surabaya.

Pasiak, T. (2008). Revolusi IQ/EQ/SQ: Menyingkap Rahasia Kecerdasan Berdasarkan Al-Quran dan Neurosains Mutakhir. Bandung: Mizan.

Poniman, F. (2012). Penjelasan Hasil Tes STIFIn. Bekasi: PT. STIFIn Fingerprint.

Poniman, F. \& Rahman, A.M. (2013). Konsep Palugada STIFIn. Jakarta: STIFIn Institute.

Rafianti, I., \& Pujiastuti, H. (2017). Analysis of Students'mathematical Power in Terms of Stifin Test. Infinity Journal, 6(1), 29-36.

https://doi.org/10.22460/infinity.v6i1.233 
Ramly, N. (2010). Rahasia \& Keajaiban Kekuatan Otak Tengah. Jakarta: Best Media Utama.

Ratna, S.D \& Ridwan. A.S. (2017). Peran Guru Fisika Dalam Penguatan Pendidikan Karakter Siswa SMA. Seminar Nasional Pendidikan dan Sains 2017. Prodi Pendidikan Fisika Pascasarjana Universitas Negeri Medan.

Suriasumantri, J.S. (2010). Filsafat IImu: Sebuah Pengantar Popular. Jakarta: Sinar Harapan.

Smith, M.K. (2002). Howard Gardner and Multiple Intelligences. The encyclopedia of informal education. https://www.schols.smcdbs.on.ca. Diakses pada 3 April 2018

Tyagi, A. (2008). Personality profiles identification using MBTI test for management students: an empirical study. Journal of the Indian Academy of Applied Psychology, 34(1), 151-162.

Wiramihardja, S. A. (2009). Pengantar Filsafat: Sistematika dan Sejarah Filsafat, Logika dan Filsafat IImu (Epistemologi), Metafisika dan Filsafat Manusia, Aksiologi. Bandung: PT. Refika Aditama. 